\title{
АНАЛІЗ СИСТЕМИ ЦЕНТРАЛЬНОГО ТЕПЛОПОСТАЧАННЯ ЗА ВИКОРИСТАННЯ СЕЗОННОГО ГЕОТЕРМАЛЬНОГО АКУМУЛЮВАННЯ В КОМБІНАЦЇ 3 СИСТЕМОЮ ВИРОБНИЦТВА ТА СПОЖИВАННЯ ВОДНЮ
}

\author{
О.В. Лисак \\ Інститут відновлюваної енергетики НАН України, \\ 02094, вул. Гната Хоткевича, 20А, м. Київ, Україна.
}

Метою статті є аналіз застосування системи центрального теплопостачання за використання сезонного геотермального акумулювання в комбінації з системою виробництва та споживання водню в загальному комплексі забезпечення енергетичних потреб будівель та супутньої інфраструктури переважно завдяки відновлюваним джерелам енергії (ВДЕ). Щодо частки в теплозабезпеченні, то система з використанням сезонного геотермального акумулювання слугує основним джерелом теплопостачання, а система з застосуванням водню є допоміжним джерелом енергії, призначеним для забезпечення теплоспоживання в період «пікового» навантаження. В даній роботі увагу до використання водню привернуто через необхідність відмови від традииійних джерел енергії, зокрема природного газу, як пікового та резервного джерела енергії в системі комбінованого центрального теплопостачання.

Хоча основна частина статті присвячена проблематиці систем иентрального теплопостачання, робота також розглядає інші елементи енергозабезпечення житлових будівель та супутньої інфраструктури. Зокрема, увагу приділено ВДЕ, які характеризуються змінним характером генераиії електроенергії та теплоти у часі, та їх зв'язку з загальною енергомережею. Також показано, як надлишок електроенергії від ВДЕ слугує джерелом для генерачії водню. Отриманий водень й використовуватиметься як для системи водневого теплопостачання, так і для потенційного забезпечення паливом водневого транспорту. Оскільки в процесі генерації теплоти від утилізаиї̈ водню застосовуються паливні елементи, то окрім теплоти, такі системи здатні виробляти й електроенергію.

В роботі надана класифікація систем сезонного геотермального акумулювання, проаналізовано схеми та принцип їх роботи, а також наведено їх порівняння.

Було проведено попередній аналіз економічної доичільності систем центрального теплопостачання за використання сезонного геотермального акумулювання в Украӥні. Для цього було виконано порівняння дійсної вартості цееттрального теплопостачання в Україні (яке здійснюється переважно за рахунок природного газу) з номінальною вартістю центрального теплопостачання за використання сезонного геотермального акумулювання. Економічний аналіз показав, щзо у випадку України нормована вартість системи центрального теплопостачання до складу якої входить сезонний геотермальний акумулятор, в якому застосовано технологію свердловин, є вищою на 80 ...200\% за вартість центрального теплопостачання від традичійних джерел енергї. Водночас, системи з застосуванням штучних озер можуть бути дешевшими на $20 \%$, але їх встановлення потребуватиме значних початкових інвестицій. Бібл. 50, табл. 3, рис. 4.

Ключові слова: водень, відновлювана енергетика, опалення, сезонне акумулювання, геотермальна енергетика.

\section{ANALYSIS OF THE DISTRICT HEATING SYSTEM WITH THE SEASONAL THERMAL ENERGY STORAGE SYSTEM TOGETHER WITH THE SYSTEM OF HYDROGEN PRODUCTION AND UTILISATION}

\author{
O. Lysak \\ Institute of Renewable Energy of the National Academy of Sciences of Ukraine, \\ 02094, 20A Hnata Khotkevycha St., Kyiv, Ukraine.
}

The aim of the article is to analyze the application of the district heating system using the underground seasonal thermal energy storage (STES) together with the system of production and consumption of hydrogen. The energy for both cases is provided by renewable energy sources (RES). Produced heat, electricity and hydrogen is used to provide energy for the residential buildings and related infrastructure. Regarding the ratio of heat supply of each system, the STES is the main source of heat supply, and the hydrogen system is an auxiliary energy source designed to provide heat consumption during the "peak" load of the district heating system. This paper shows the use of hydrogen due to the need to abandon conventional energy sources, in particular natural gas, as a "peak" and backup energy source of district heating systems.

(C) О.В. Лисак, 2020 
Although the main part of the article is devoted to the issue of district heating systems, the paper also analyzes other elements of energy supply of residential buildings and related infrastructure. In particular, attention is paid to variable RES, which are characterized by the variable output of electricity and heat production through time, and their connection to the power grid. It is also shown how the excess electricity from RES serves as a source for hydrogen generation. The obtained hydrogen is to be used both for the hydrogen heating system and for the potential fuel supply of hydrogen vehicles. Since fuel cells are used in the process of heat generation from hydrogen utilization, in addition to heat, such systems are able to generate electricity.

The paper provides the classification of STES describing both their schemes and, their operational principles. Their comparison of different STES is also given. The preliminary analysis of the economic feasibility of the district heating systems with STES was conducted. It was done through the comparison of the current cost of the convenient district heating system, which uses natural gas in Ukraine, and the levelized cost of energy (LCOE) from the district heating system, which includes the STES. The economic analysis showed that in the case of Ukraine the LCEO of the district heating systems using borehole thermal energy storage is $80 \ldots 200 \%$ more expensive than the cost of the convenient district heating. At the same time, the LCOE of the district heating systems using pit thermal energy storage may be $20 \%$ cheaper but the installation of such systems requires significant initial investment. Ref. 50, table. 3, fig 4. Keywords: heating, hydrogen, renewable energy, seasonal thermal energy storage, geothermal energy.

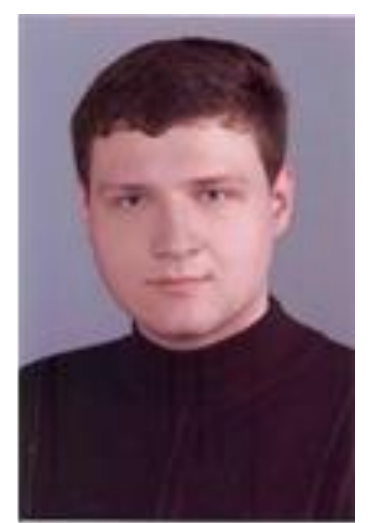

О.В. Лисак

O. Lysak
Відомості про автора: провідний інженер Інституту відновлюваної енергетики НАНУ.

Освіта: закінчив 2011 р. Київський національний університет будівництва i архітектури за спеціальністю «Теплогазопостачання і вентиляція».

Наукова сфера: відновлювані джерела енергії, геотермальна енергетика, системи акумулювання теплоти.

Публікації: більше 20.

ORCID: 0000-0002-4934-0685

Контакти: тел./факс +38(044)206-28-09

e-mail: geotherm@ukr.net
Author information: chief engineer at Institute for Renewable Energy, National Academy of Sciences of Ukraine.

Education: graduated from Kyiv National University of Construction and Architecture in 2011 with a degree on heat $\&$ gas supply and ventilation.

Research area: renewable energy sources, geothermal energy, heat storage systems.

Publications: more than 20.

ORCID: 0000-0002-4934-0685

Contacts: phone/fax +38(044)206-28-09

e-mail: geotherm@ukr.net
Вступ. За останні роки відбулись значні зміни в системі генерації та споживання енергії, зокрема збільшилась частка відновлюваних джерел енергії (ВДЕ), що мотивовано необхідністю боротьби з загрозами негативних змін клімату [1]. Однак при впровадженні ВДЕ необхідно враховувати те, наскільки регульованою є генерація від нього. У разі, якщо ВДЕ самостійно не регулює потужність виробництва енергії відповідно до потреби у споживанні енергії, виникає необхідність у створенні системи акумулювання енергії. Типами ВДЕ, які в [2,3] характеризувались як змінні ВДЕ чи ВДЕ зі змінною потужністю виробництва, $\epsilon$ сонячна та вітрова енергетика.

Сонячна енергетика стає поширеним джерелом теплопостачання будівель та споруд для забезпечення роботи систем опалення. Для цього вироблена в теплий період року від сонячних колекторів теплота має бути акумульованою та надалі використаною для забезпечення теплопостачання в холодний період року. Як правило, такі акумулятори теплоти розташовують приховано під землею і загалом їх відносять до систем сезонного геотермального акумулювання [4].

Системи центрального теплопостачання, які отримують енергію від систем сезонного геотермального акумулювання існують вже тривалий час [5], але лише порівняно нещодавно їх вартість в деяких країнах світу стала конкурентоспроможною у порівнянні 3 традиційними системами центрального теплопостачання [6]. Таке зниження вартості обгрунтовано декількома причинами. По-перше, відбулось значне зниження вартості сонячних колекторів [7]. По-друге, було накопичено значний досвід 3 впровадження таких систем, що дозволило оптимізувати їх конструкцію та будівництво зокрема щодо зменшення коштів на встановлення та експлуатацію [8]. 
Аналіз системи сезонного геотермального акумулювання можливо розглядати виокремлено, а можливо й як складову системи енергозабезпечення комплексу будівель та споруд [9,10]. Останній підхід набуває все більшого вжитку в наукових роботах, оскільки демонструє можливість поєднання відразу декількох типів ВДЕ для комплексного забезпечення енергоспоживання. Саме тому в даній роботі наведено принципові рішення 3 застосування надлишково виробленої електроенергії від ВДЕ для виробництва водню з води та подальшого його застосування для теплопостачання будівель чи як палива для транспорту [11]. Це пов'язано з тим, що водень в світі все частіше розглядають альтернативою природному газу як резервному джерелу енергії.

Метою дослідження $\epsilon$ аналіз систем центрального теплопостачання за використання сезонного геотермального акумулювання в комбінації 3 системою виробництва та споживання водню в загальному комплексі енергозабезпечення будівель та споруд.

\section{Формулювання завдання.}

Для виконання поставленої мети були сформовані наступні задачі:

- проаналізувати сучасні рішення щодо застосування водню для енергозабезпечення будівель та транспорту;

$$
\text { - проаналізувати }
$$

типи

систем

акумулювання теплоти;

- проаналізувати сучасний стан розвитку систем сезонного геотермального акумулювання;

- розробити схему системи центрального теплопостачання за використання сезонного геотермального акумулювання в комбінації 3 системою виробництва та споживання водню;

- проаналізувати можливий економічний ефект від впровадження системи сезонного геотермального акумулювання в умовах України.

Аналіз застосування водню для енергозабезпечення будівель та транспорту.

Перш ніж аналізувати дійсний досвід застосування водню в розглянутій тематиці, необхідно зазначити, що водень у порівнянні 3 природним газом $є$ більш вибухонебезпечною речовиною [12]. Безпечним до останнього часу використання водню вважалось лише в умовах промислових підприємств. Але 3 розвитком технологій ризик при використанні водню стає лише незначно вищим за ризик при використанні природного газу, тому поширення водню поза межі промислових технологій вважається виправданим рішенням [13]. Заходи безпеки при розробці систем споживання водню в цілому $є$ аналогічними заходам при споживанні природного газу.

Кількість робіт, які досліджують водень як паливо для теплопостачання будівель та споруд досі $є$ незначною [2]. Загалом, існує декілька технологічних рішень щодо того, як саме конвертувати водень в теплоту: використання водню для комбінованого виробництва теплоти та електроенергії (використання водневих паливних елементів), використання водневих котлів чи, навіть, живлення теплового насоса за допомогою водню [13]. Так само, розглядаються й технології застосування суміші природного газу та водню [14].

Що стосується економічної доцільності, то для більшості країн застосування водню як палива для енергозабезпечення будівель та споруд 3 економічної точки зору є більш витратним, ніж застосуванням теплопостачання від природного газу, чи застосування теплових насосів. Проте існує тенденція до зниження вартості водню, що має зробити його застосування більш економічно доцільним [15].

Впровадження водневої технології потребує державної підтримки, яка б дозволила виробникам оптимізувати конструкцію приладів та налагодити технологічне виробництво. Зокрема, програми по створенню систем водневого енергозабезпечення існують в Японії та Кореї, де й були впроваджені індивідуальні системи з комбінованого виробництва теплоти та електроенергії за допомогою паливних елементів $[13,16]$. Теплова потужність таких установок складає $1 \ldots 3$ кВт $[13,17]$. За допомогою програми державної підтримки виробники отримали змогу виконати апробацію запропонованих технологічних рішень і завдяки оптимізації виробництва знизили вартість виробництва приладів в період з 2004 по 2010 рік приблизно в чотири рази разом з підвищенням тривалості експлуатаційного терміну приладів $[13,16]$. 
Разом 3 тим, 3 огляду на безпеку роботи, кращим рішенням було б створення водневих систем центрального теплопостачання, за якого водневе обладнання було б розташовано на безпечній відстані від кінцевих споживачів.

Далі розглянемо застосування водню як палива для водневого транспортних засобів. На даному етапі існують два напрямки [18]. Перший напрямок полягає в безпосередньому застосуванні електроенергії для живлення електричних акумуляторів, від якого й працюватиме даний транспортний засіб. Другий напрямок використання електроенергії для генерації водню, який буде джерелом живлення паливних елементів розглянутого транспортного засобу.

Автомобільний концерн Volkswagen AG (Німеччина) вважає [19], що для пасажирських автомобілів більш вигідним $є$ застосування електричних акумуляторів, оскільки паливні елементи споживатимуть у 2...3 рази більше електроенергії для подолання тієї ж самої відстані. Але дана перевага зникає при розгляді типів транспортних засобів 3 більш потужними двигунами (вантажівок, автобусів тощо).

Автомобільні концерни Hyndai (Корея) та Toyota (Японія) підтримують не лише розвиток [20] водневого транспорту 3 потужними двигунами, але й пасажирського транспорту. Поперше, це було викликано необхідністю створення спільної інфраструктури для заправлення як для вантажівок, так і для легкових автомобілів. По-друге, для обох країн імпортування водню, виробленого в країнах 3 високоефективними ВДЕ, та подальшого живлення водневого транспорту було більш економічно виправданим рішенням, ніж створення ВДЕ з меншою ефективністю в даному регіоні для живлення транспорту з електричними акумуляторами.

\section{Аналіз типів систем акумулювання теплоти. \\ В літературі існує декілька основних типів класифікації систем сезонного акумулювання}

теплоти (рис. 1). В даній роботі увагу приділено тому, яким чином в ту чи іншу класифікацію вписується система сезонного геотермального акумулювання теплоти.

Найбільш розповсюдженою $є$ класифікація згідно 3 принципом акумулювання теплоти [2124]: 1) $з$ явним акумулюванням теплоти, коли використовують зміну температури тіла для акумулювання теплоти за незмінного стану матеріалу для акумулювання теплоти; 2) 3 фазовим акумулюванням теплоти, коли використовують теплоту фазового переходу для акумулювання теплоти; 3) 3 термохімічним (або хімічним) акумулюванням теплоти, коли використовують теплоту оборотних хімічних реакцій. Кожна 3 наведених систем має власні підтипи, але переважно увага в літературі приділяється системам «теплового» акумулювання теплоти: (явної та фазової [22]). 3 них лише системи 3 явним акумулюванням теплоти мали практичне втілення в системах сезонного геотермального акумулювання.

Іншим методом класифікації $є$ поділ систем в залежності від тривалості роботи системи акумулювання [21-27]: 1) добові; 2) з тривалістю роботи від декількох діб до тижня $[28,29]$, 3) сезонні. Хоча в роботі йде мова про системи сезонного акумулювання, в технологічних схемах рішень систем центрального теплопостачання від сезонних геотермальних акумуляторів використовують й проміжні акумулятори для накопичення теплоти, достатньої для забезпечення потреб теплопостачання від доби до тижня.

Також системи акумулювання можуть поділятись залежно від того, який тип енергії підводять до акумулятора теплоти: електроенергію чи теплоту [6]. У випадку сезонних геотермальних акумуляторів відбувається споживання теплоти, виробленої сонячними колекторами. 


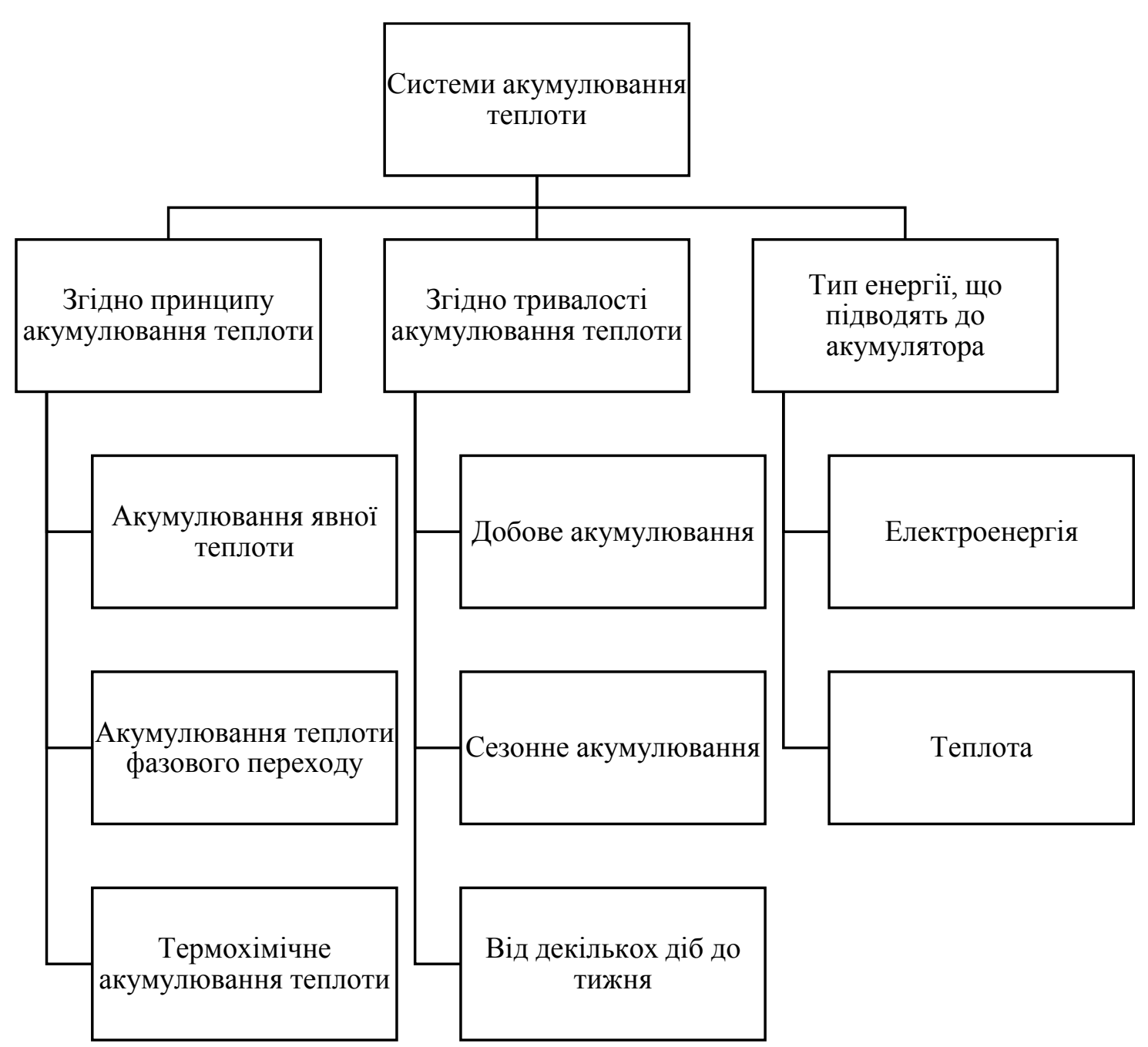

Рис. 1. Класифікація систем акумулювання теплоти.

Fig. 1. Types of thermal energy storage.

\section{Аналіз сучасного стану розвитку сезонних геотермальних \\ теплових}

\section{акумуляторів.}

В літературі найчастіше виділяють чотири основні типи систем сезонного геотермального акумулювання теплоти [6,25-27,30-34], які представлено нижче разом 3 назвами в англомовній літературі (рис. 2):

1.3 використанням баків-акумуляторів (рис. 2a):

- tank thermal energy storage (TTES) в [30,31,34];

- hot water thermal storage (HWTS) в [25,32];

- hot water heat store (HWHS) в [33];
- hot water thermal energy storage (HWTES) в [27,35];

2. з використання штучних озер (рис. $2 \mathrm{~b}-\mathrm{d}$ ):

- pit thermal energy storage (PTES) в [30,31,34];

- water gravel pit storage (WGPS) в [27];

- gravel water heat store (GWHS) в [26,33];

- gravel-water thermal energy storage (GWTES) в [27,35];

3. 3 використанням свердловин (рис. 2e):

- borehole thermal energy storage (BTES) в [6,30,31,34];

- duct thermal energy storage (DTES) в [27];

- duct heat store (DTS) в [26,33]; 
4. 3 акумулюванням теплоти у водоносному горизонті (рис. 2f):

- aquifer thermal energy storage (ATES) в [6,26,30,31,34];

- aquifer heat storage (HTS) в [33].

Існують й інші види систем акумулювання теплової енергії, зокрема 3 використанням закритих шахт чи 3 відпрацьованих нафтових чи газових свердловин [6,34], але вони не набули широку вжитку, тому в цій роботі не розглянуті.

Розглянемо принцип роботи кожного 3 наведених акумуляторів теплоти:

1. Система з використанням баківакумуляторів (рис. 2a) складається 3 теплоізольованого водяного баку-акумулятору, що пов’ язаний з системою подачі та відведення теплоти [5]. Акумулювання теплоти здійснюється шляхом підведення до бакуакумулятору нагрітого в теплий період року теплоносія (як правило, води). Аналогічно, в холодний період року, коли виникає потреба у використанні акумульованої теплоти, його отримують шляхом відбору нагрітої води 3 баку-акумулятора.

Що стосується особливості конструкції баків-акумуляторів, то варто звернути увагу на два фактори: тип розміщення баку-акумулятора та максимальне значення температури теплоносія в ньому. Переважно застосовується підземне розміщення баків-акумуляторів для заощадження надземної площі та використання навколишнього грунту, як додаткового прошарку теплоізоляції [27,30,31]. Що стосується максимально значення температури в баку-акумуляторі, то їі значення не перевищує $100{ }^{\circ} \mathrm{C}$ (температури кипіння води), тому в даній роботі не розглядаються негативні ефекти притаманні акумулюванню високотемпературного теплоносія i, власне, розглядаються лише баки-акумулятори без додаткового тиску [5,8].

Значне ускладнення в роботу розглянутих систем вносить температурна стратифікація - розшарування води, зумовлене різницею густини. Тобто, вода 3 найвищою температурою буде знаходитись у верхній частині баку-акумулятора, а найхолодніша - у нижній. Тому забір та подачу води в бакакумулятор необхідно здійснювати згідно 3 цим розшаруванням. В $[32,33]$ пропонувалось влаштовувати забір теплоносія у двох точках: одна розташована в самому верху бакуакумулятора, інша - на одній третій відстані від верху баку-акумулятора. Таке рішення забезпечувало більшу гнучкість в виборі необхідного значення температури теплоносія 3 баку-акумулятора. 

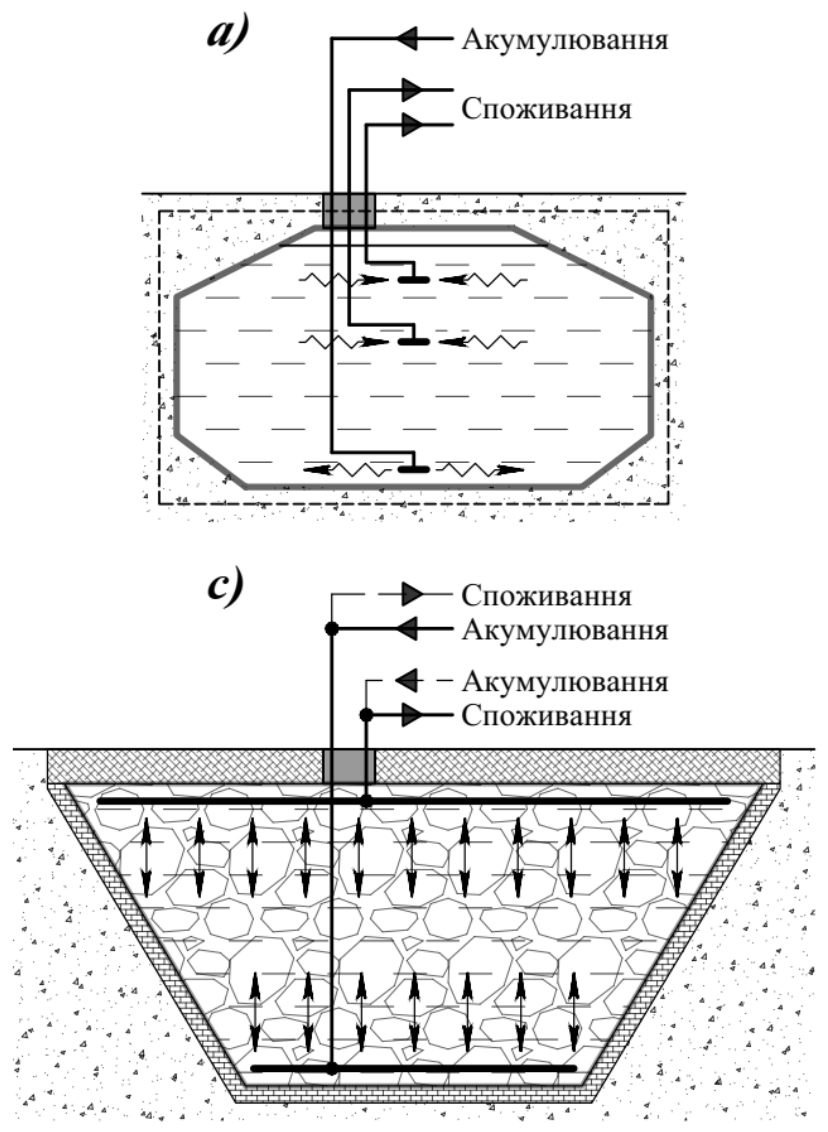
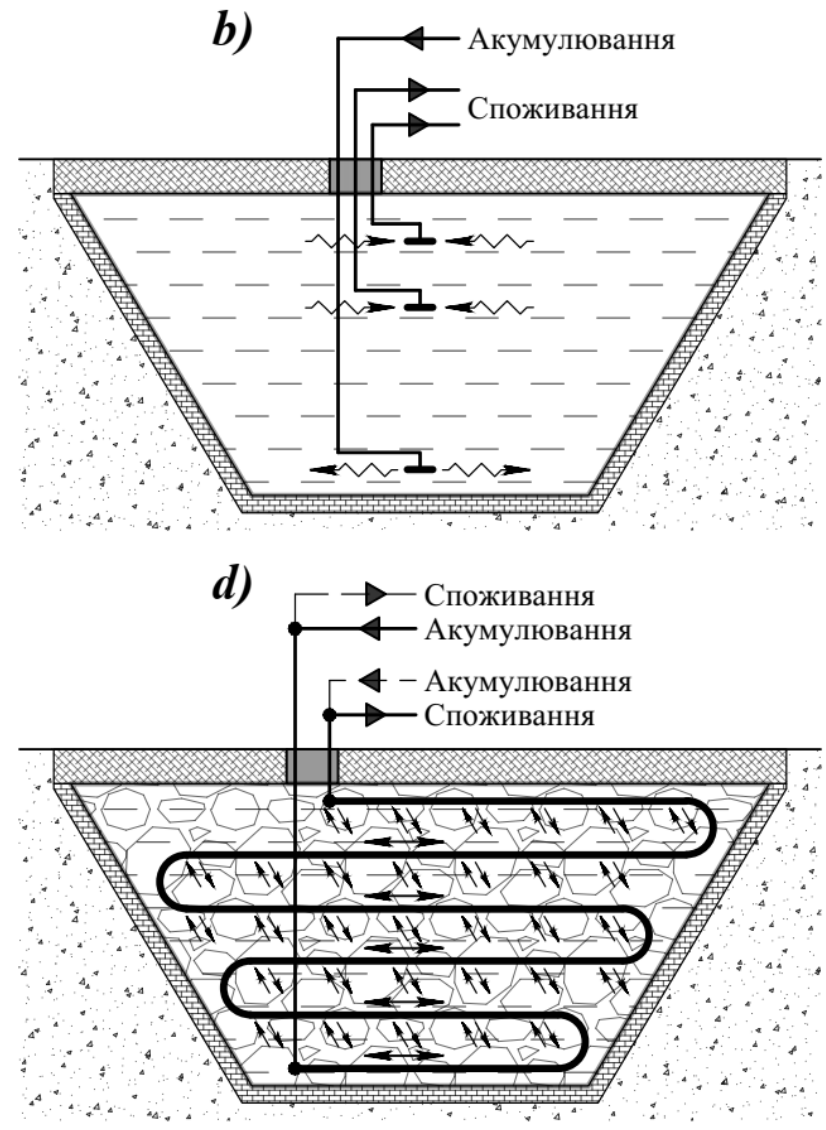

f)
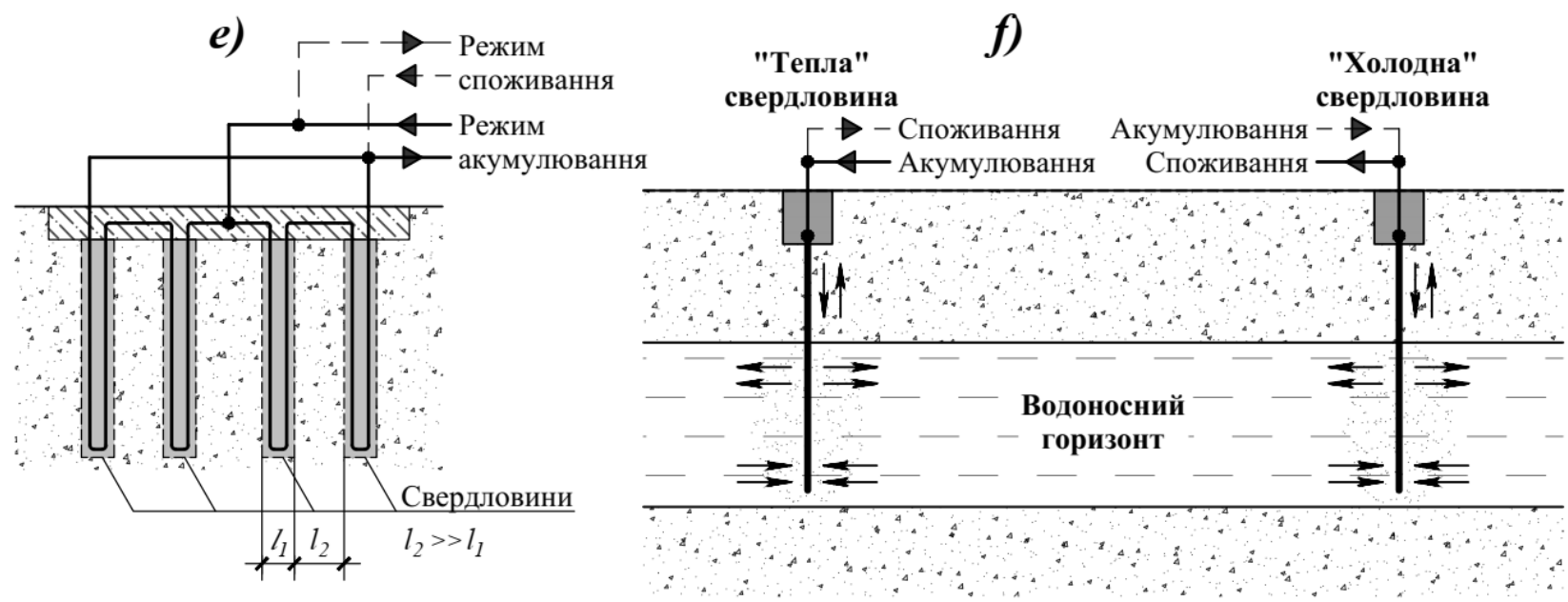

Рис. 2. Принципові схеми роботи сезонних акумуляторів теплової енергії:

a) - з використанням баків-акумуляторів, $b$ ) - з використанням штучних озер (для акумулювання теплоти застосовано воду); c) - з використанням штучних озер (для акумулювання теплоти застосовано суміш гравію та води) з прямою системою «зарядження» та «розрядження» акумулятора; $d$ ) - з використанням штучних озер (для акумулювання теплоти застосовано суміш гравію та води) з непрямою системою «зарядження» та «розрядження» акумулятора; е) використанням свердловин; f) - з використанням водоносного горизонту.

Fig. 2. Types of seasonal thermal energy storage:

a) - tank thermal energy storage, $b$ ) - pit thermal energy storage (water used as a heat storage medium); $c$ ) - pit thermal energy storage (the mix of gravel and water used as a heat storage medium) with direct charging and discharging; $d$ ) - pit thermal energy storage (the mix of gravel and water used as a heat storage medium) with indirect charging and discharging; $e$ ) - borehole thermal energy storage; $f$ ) - aquifer thermal energy storage. 
2. Системи з використанням штучних озер (рис. 2b-d) є схожими на системи з використанням баків-акумуляторів, але замість баку-акумулятора використовують оточуюче середовище для конструкції системи сезонного геотермального акумулювання. Спочатку створюється котлован штучного озера. Далі в ньому облаштовують теплову ізоляцію нижньої та бокових сторін. Після цього штучне озеро наповнюють матеріалом для акумулювання теплоти: водою чи сумішшю води з гравієм. По завершенню цього відбувається встановлення теплоізоляційного матеріалу, що закриває верхню сторону озера.
Таким чином утворюється закритий резервуар $[26,30,31]$.

Вибір матеріалу для акумулювання теплоти впливає на розміри штучного озера (табл. 1): використання гравію призводить до більших розмірів штучного озера внаслідок меншої густини накопичення теплоти $q$, МДж/ $\mathrm{M}^{3}$ :

$$
q=c_{p} \cdot \rho \cdot \Delta T
$$

де $c$ - питома теплоємність матеріалу, Дж/(кг К $) ; \quad \rho-\quad$ густина, $\quad$ кг/м3; $\quad \Delta T$-перепад температури в акумуляторі, К.

Таблиця 1. Характеристики матеріалу для акумулювання теплоти.

Table 1. The parameters of heat storage materials.

\begin{tabular}{|c|c|c|c|c|c|}
\hline Матеріал & Джерело & $\begin{array}{l}\text { Теплоємність } \\
c_{\mathrm{p}}, \text { Дж/(кг·К) }\end{array}$ & $\begin{array}{l}\text { Густина } \\
\rho, \kappa г / \mathrm{M}^{3}\end{array}$ & $\begin{array}{c}\text { Перепад температури } \\
\Delta T, \mathrm{~K}\end{array}$ & $\begin{array}{c}\text { Густина накопичення } \\
\text { теплоти } q, \text { МДж/м }\end{array}$ \\
\hline Вода & [21] & 4190 & 1000 & 20 & 84 \\
\hline Гравій & [36] & 880 & 2560 & 20 & 45 \\
\hline
\end{tabular}

Вибір матеріалу для акумулювання теплоти впливає на вибір схеми підводу та відводу теплоти від акумулятора. Якщо застосовується вода, то схема підводу та відводу теплоти $\epsilon$ аналогічною системі з використанням баків-акумуляторів (рис. $2 b)$. У випадку застосування суміші води та гравію $\epsilon$ два варіанти підводу та відводу теплоти: прямий та непрямий [31].

Прямий метод підводу та відводу теплоти полягає у безпосередньому підведенні розігрітого теплоносія до штучного озера для акумулювання теплоти та, відповідно, відбору теплоносія зі штучного озера для забезпечення потреб в теплопостачанні. Хоча запропонований метод $\epsilon$ схожим на системи акумулювання 3 використанням води, конструктивне рішення $€$ відмінним (рис. 2c): подача чи забір теплоносія може відбуватись відразу в декількох точках однією площини штучного озера. Недоліком цього методу $€$ забруднення труб, через які здійснюється підвід та відвід теплоносія [30,31].
Непрямий метод підводу та відводу теплоти полягає у використанні проміжного теплообмінника, що розміщено в штучному озері (рис. 2d). Теплообмінник виконують у вигляді системи труб, через які здійснюється теплообмін між проміжним теплоносієм, що проходить через теплообмінник, та матеріалом для акумулювання теплоти в штучному озері. Як правило для акумулювання теплоти схема руху проміжного теплоносія по теплообміннику відбувається знизу-вверх, та навпаки, для відбору акумульованої теплоти схема руху проміжного теплоносія відбувається зверху-вниз. На відміну від прямого методу забруднення теплоносія $є$ відсутнім, але використання проміжного теплообмінника призводить до більших витрат електроенергії на транспортування теплоносія в системі [31].

3. Системи з використанням свердловин (рис. 2е) застосовують для акумулювання теплоти грунт, а підведення тепла до грунту (і відповідно, відведення тепла від грунту) здійснюється через 
вертикальні свердловини. прокладено U-подібні труби, по яких циркулює теплоносій, що в теплий період року підводить тепло до грунту, а в холодний період року відводить накопичене грунтом тепло. Грунт здатний акумулювати лише $20 \ldots 30 \%$ від тієї кількості тепла, що здатна акумулювати вода за аналогічного перепаду температур: тобто, системи займатимуть значно більший об'єм [30,31].

Як правило, свердловини в таких акумуляторах поділені на групи. Кожну групу формують таким чином, аби поєднувати одну за одною свердловини, що розташовані біля центра акумулятора в напрямку до тих свердловин, що розташовані на зовнішньому кордоні акумулятору. Якщо необхідно підводити теплоту до акумулятора, то рух теплоносія відбувається від центру акумулятора до зовнішніх меж. Якщо потрібно відводити теплоту, то рух теплоносія $\epsilon$ зворотним [27].

4. Системи з використанням водоносних горизонтів (рис. 2f) застосовують для акумулювання теплоти водоносні горизонти: водопроникний шар гірської породи, що вміщує воду. Система складається 3 комплексу «холодних» та «теплих» свердловин. «Холодними» називають ті свердловини, до яких надходить охолоджений теплоносій, а «теплими» відповідно ті, куди надходить нагрітий теплоносій [37].

Такі системи, як правило, намагаються одночасно використовувати як для теплопостачання, так і холодопостачання. В теплий період року вода відводиться 3 «холодної» свердловини, що, відповідно, містить холодну воду. Ця вода використовується для охолодження теплоносія, що циркулює в основній системі холодопостачання. Теплообмін здійснюється, як правило, через теплообмінник. Далі вже нагріта вода 3 «холодної» свердловини надходить до «теплої» свердловини. В холодний період року вода 3 «теплої» свердловини відводиться до теплообмінника та віддає теплоту до основної системи теплопостачання. Охолоджена вода надалі поступає в «холодну» свердловину $[34,38]$.

$$
\text { Якщо узагальнювати технічні }
$$

характеристики систем сезонного геотермального акумулювання теплоти (табл. 2), то помітні значні відмінності між можливими мінімальними та максимальними значеннями кількості накопиченої теплової енергії для акумуляторів одного й того ж типу. Зокрема, відмінності між значеннями густини акумулювання теплоти в [30,31] та [33] полягали в тому, що в [30,31] наведені дані лише про низькотемпературні типи систем сезонного геотермального акумулювання, a в [33] розглядалась й високотемпературні системи.

Таблиця 2. Порівняння систем сезонного геотермального акумулювання теплоти.

Table 2. The comparison of underground seasonal thermal energy storage systems.

\begin{tabular}{|l|c|c|c|c|c|}
\hline \multirow{2}{*}{$\begin{array}{l}\text { Характеристика } \\
\text { акумулятора }\end{array}$} & \multirow{2}{*}{$\begin{array}{c}\text { Джерело } \\
\text { літератури }\end{array}$} & $\begin{array}{c}\text { Бак- } \\
\text { акумулятор }\end{array}$ & \multicolumn{4}{|c|}{$\begin{array}{c}\text { Штучне } \\
\text { озеро }\end{array}$} & $\begin{array}{c}\text { Свердловини } \\
\text { в грунті }\end{array}$ & $\begin{array}{c}\text { Водоносний } \\
\text { горизонт }\end{array}$ \\
\hline $\begin{array}{l}\text { Тип тепло- } \\
\text { акумуляційного } \\
\text { матеріалу }\end{array}$ & $\begin{array}{c}{[25,27,30-} \\
35]\end{array}$ & Вода & $\begin{array}{l}\text { • Вода; } \\
\text { Суміш води } 3 \\
\text { гравієм. }\end{array}$ & Грунт & $\begin{array}{l}\text { • Вода та пісок; } \\
\text { Вода та гравій }\end{array}$ \\
\hline $\begin{array}{l}\text { Густина } \\
\text { акумулювання } \\
\text { теплоти, } \\
\text { кВт·год/м }\end{array}$ & {$[33]$} & $60 \ldots 80$ & $30 \ldots 50$ & $15 \ldots 30$ & $30 \ldots 40$ \\
\cline { 2 - 6 } & {$[30,31]$} & $20 \ldots 80$ & - & $5 \ldots 30$ & $5 \ldots 10$ \\
\hline
\end{tabular}


Що стосується економічної доцільності, то ситуація $\epsilon$ наступною [25,27,30-35]. Найбільш дорогими у встановленні, але, одночасно, дешевими в експлуатації вважаються системи 3 баками-акумуляторами та штучними озерами. Навпаки, найбільш дешевими у встановленні, але дорогими в експлуатації вважаються системи 3 застосуванням водоносного горизонту. Системи 3 застосуванням свердловин займають проміжне значення щодо вартості їх встановлення та експлуатації. Проте при виборі системи потрібно враховувати й такі фактори, як загальна потужність системи. Так, системи з бакамиакумуляторами та штучними озерами є найбільш доцільними за значного об'єму акумульованої теплоти. Водночас, системи 3 використанням свердловин матимуть кращі економічні показники за меншої ступені навантаження [8].

Система енергозабезпечення комплексу будівель за допомогою генерування відновлюваної електроенергії та виробництва теплоти й водню 3 сезонним геотермальним акумулюванням теплоти

Запропонована система створена шляхом поєднання основних технологічних рішень двох проектів: "Drake Landing Solar Community" $[10,39,40], 3$ якої була запозичена концепція роботи сезонного геотермального акумулятора, та "Power-to-H3" [9], з якого була узята концепція видобутку водню (рис. 3).

Дана система складається 3 декількох елементів:

1. Комплексу ВДЕ $з$ непостійною у часі генерацією електроенергії та теплової енергії. Як ВДЕ розглянуто вітрові електростанції та гібридні сонячні колектори. В той час як вітрові електростанції виробляють лише електроенергію, гібридні сонячні колектори вироблять одночасно й теплоту, й електроенергію [41]. Такі колектори утворені шляхом поєднання фотоелектричного перетворювача 3 сонячним колектором для виробництва теплової енергії [42]. Прийняте рішення не обов'язково $є$ універсальним, зокрема можливим є створення окремих одна від одної сонячних електростанцій для виробництва електроенергії та сонячних колекторів для виробництва теплоти [43]. Даний комплекс слугує для живлення споживачів електроенергію, виробництва теплоти й водню.

2. Системи акумулювання електроенергії, призначеної для балансу перетоків електроенергії.

3. Трансформаторної підстанції, яка використовується для передачі (продажу) або прийняття (купівлі) електроенергії від енергосистеми.

4. Розподільчого теплового пункту, який слугує для короткотривалого акумулювання теплоти, а також містить пункт додаткового підігріву з паливним елементом для генерації теплоти та електроенергії.

5. Системи перетворення надлишково виробленої електроенергії в водень та іi розподілення до споживачів: системи теплопостачання житлових будівель та заправнозливної станції для автомобілів, вантажівок, автоцистерн тощо.

6. Споживачів (житлового комплексу), які споживають вироблену теплоту та електроенергію.

7. Системи сезонного геотермального акумулювання з використанням свердловин. Дана система споживає теплоту від сонячних колекторів. Накопичення теплоти відбувається в теплий період року, а відбір - в холодний період року. Дана система має використовувати важливу особливість проекту "Drake Landing Solar Community" [10,39,40], а саме: ввід в експлуатацію системи 3 використанням свердловин відбувається не в перший рік роботи, а поступово (рис. 4): акумулятор розігрівається до більш високих значень температури протягом перших років з часу свого запуску, що має суттєво полегшити відбір теплоти від акумулятора. Так само це має дозволити уникнути необхідності додаткового підвищення температури теплоносія, який вже розігрітий завдяки акумулятору (зокрема, не буде необхідним тепловий насос). Але за потреби запропонована система сезонного геотермального акумулювання може бути замінена на іншу. 


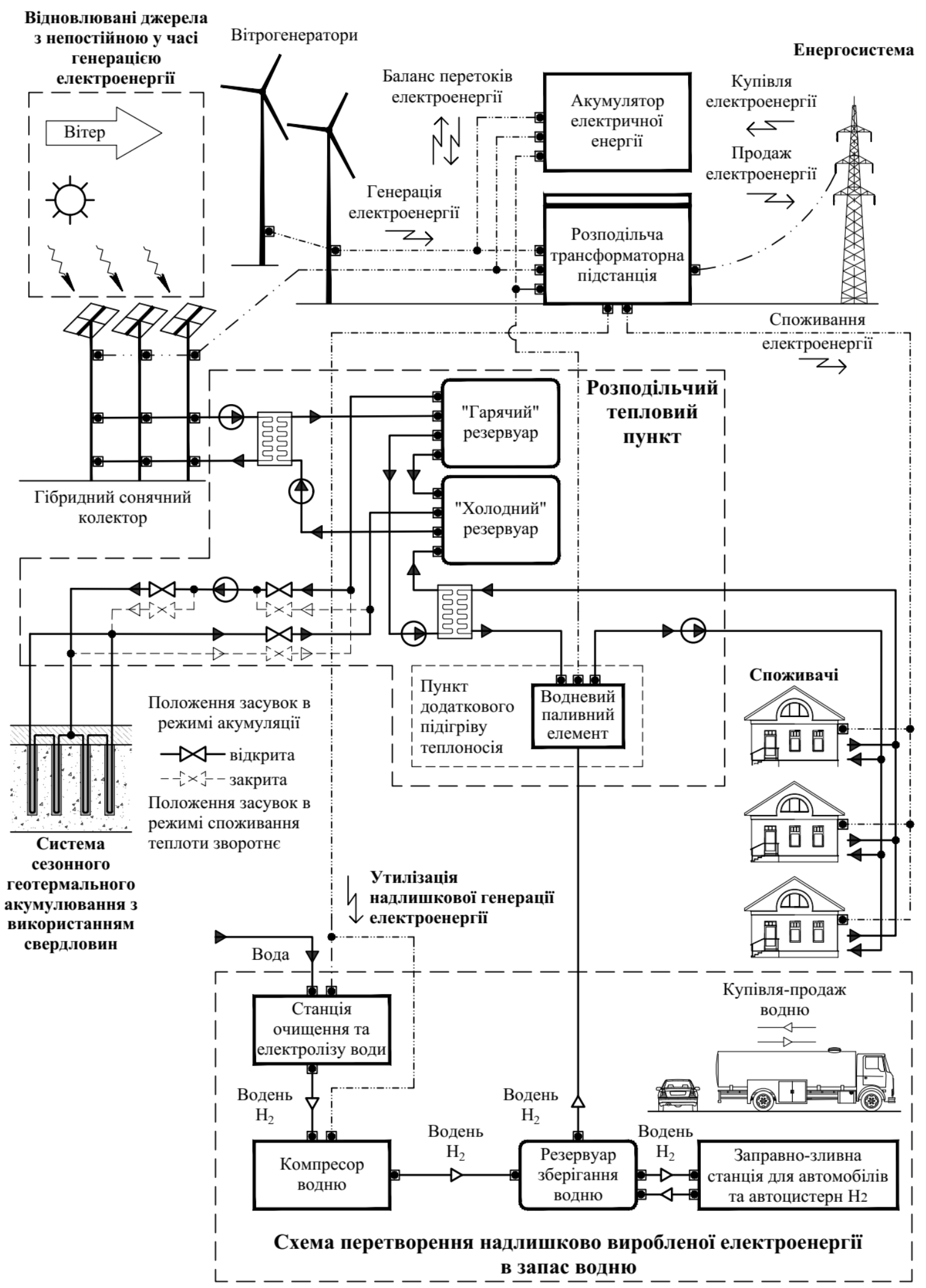

Рис. 3. Система енергозабезпечення комплексу будівель за допомогою генерування відновлюваної електроенергії та виробництва теплоти й водню з сезонним геотермальним акумулюванням теплоти.

Fig. 3. The system of energy supply of a neighborhood with the renewable electricity generation with heat and hydrogen production together with an underground seasonal thermal energy system. 


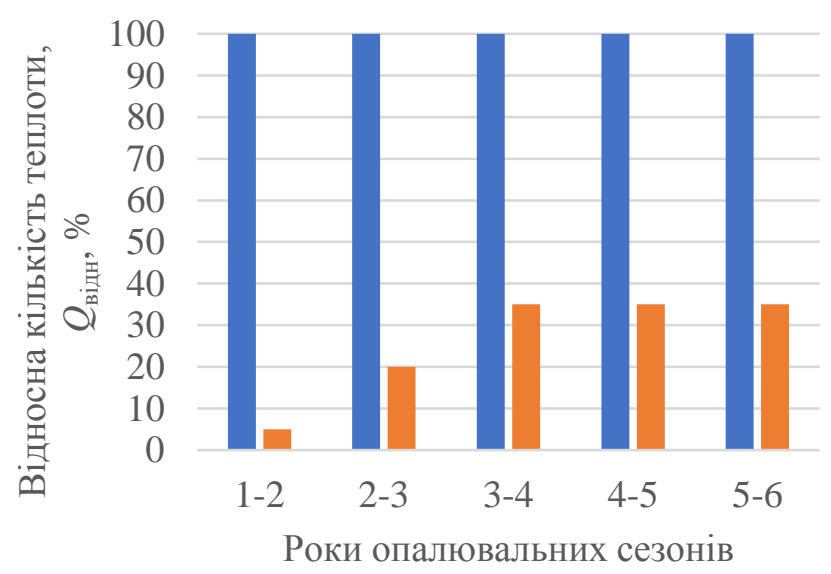

- Акумульована теплота Спожита теплота

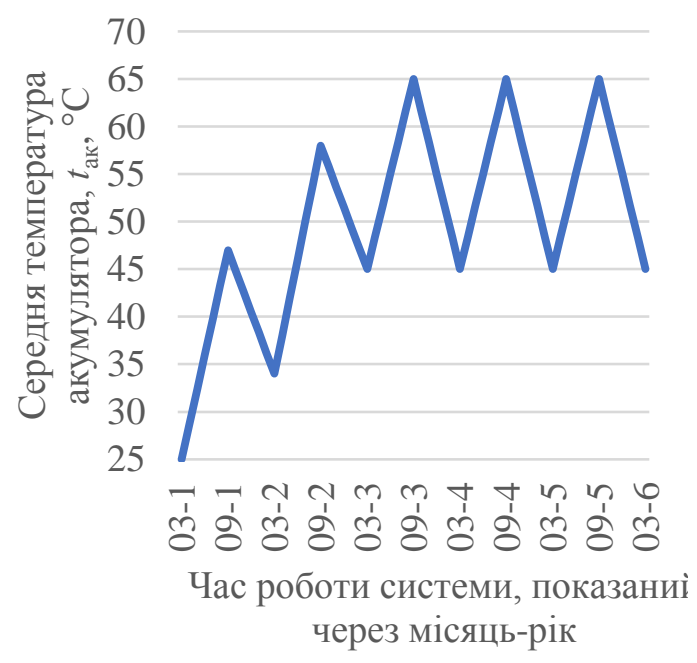

b)

Примітка: дана схема була виконана згідно [40], але спрощена для демонстрації процесу підводу та відводу теплоти за рахунок нехтування щорічними відмінностями щодо кількості акумульованої теплоти та кількості спожитої теплоти.

Рис. 4. Спрощена схема роботи системи сезонного геотермального акумулювання теплоти з використанням свердловин: a) акумулювання теплоти та підведення теплоти; b) зміна середньої температури в об'ємі акумулятора.

Fig. 4. Simplified scheme of operation of a borehole thermal energy storage system: a) heat supply and heat consumption; b) change of the average temperature in the thermal energy storage volume.

Розглянемо принцип запропонованої системи.

Вироблена ВДЕ електроенергія підводиться до розподільчої трансформаторної підстанції. Для балансу перетоків електроенергії від ВДЕ до системи електропостачання може використовуватись потужний акумулятор електроенергії. Даний акумулятор може слугувати не тільки для підвищення надійності роботи системи для внутрішніх споживачів, але й для того, аби система ВДЕ забезпечувала постачання електроенергії відповідно до встановленого графіку (така вимога може бути присутньою при встановленні ВДЕ) та в обсягах, які передбачено в договорі 3 енергосистемою. Коректна співпраця 3 енергосистемою $\epsilon$ запорукою безаварійної експлуатації самої ВДЕ.

Електроенергія може використовуватись як для енергозабезпечення внутрішніх споживачів, так і для виробництва водню.

Генерація водню відбувається шляхом електролізу води, яка попередньо проходить очищення. Метод очищення залежить від джерела води: наприклад, в [9] розглядалась дощова вода. Отриманий водень проходить потім через компресор для його стиснення і подальшого зберігання. Надалі отриманий водень використовується як для забезпечення теплопостачання будівель та споруд, так і для заправки автомобільного транспорту. Оскільки теплопостачання 3 використанням водню здійснюється за допомогою паливних елементів, то, відповідно до принципу їх роботи, одночасно відбуватиметься виробництво електроенергії. Але періоди виробництва водню та періоди його споживання паливними елементами системи теплопостачання, як правило, не збігаються в часі [9]. Тому вироблену паливним елементом супутню електроенергію можна використовувати на будь-які поточні потреби.

Принцип роботи системи сезонного геотермального акумулювання $є$ наступним.

Розігрітий теплоносій від системи гібридних сонячних колекторів підводиться до розподільчого теплового пункту, де потрапляє до теплообмінника, нагріває проміжний теплоносій (віддає отриману теплоту), та повертається до системи гібридних сонячних колекторів, де теплоносій знову розігрівається. Розігрітий проміжний теплоносій підводиться до системи акумулювання теплоти 3 двома бакамиакумуляторами, аналогічну 3 проектом "Drake 
Landing Solar Community" [10,39,40]. Дана система 3 баками-акумуляторами слугує для організації більш рівномірного підведення та відведення теплоти від системи сезонного геотермального акумулювання згідно принципу, наведеному вище.

Проміжний теплоносій, накопичений в баках-акумуляторах, використовується для підігріву теплоносія, який підводиться безпосередньо до споживачів теплоти. Додатковим джерелом теплоти може слугувати водневий паливний елемент.

\section{Аналіз економічного впровадження систем геотермального акумулювання}

підгрунтя сезонного

Як зазначалось вище, в літературі існують значні розбіжності в пропозиціях щодо рекомендованого значення вартості систем сезонного акумулювання теплової енергії. Найбільш детальним оглядом таких технологій $\epsilon$ звіт [8], виконаний Міжнародним Енергетичним Агентством (англ. International Energy Agency) відповідно до «Програми сонячного теплопостачання та холодопостачання» (Solar Heating and Cooling Program).Згідно 3 даним звітом [8] була розглянуто два випадки центрального теплопостачання 3 використанням сезонного геотермального акумулювання: 3 використанням свердловин та 3 використанням штучних озер. Суттевою відмінністю запропонованих варіантів було те, що за використання свердловин розглядалось й розміщення сонячних колекторів на даху обслуговуваних будівель, в той час як за використання штучних озер сонячні колектори розташовувались безпосередньо на землі.

Наведена типова система з використанням свердловин мала встановлену потужність в 3,5 МВт та займала площу близько $5000 \mathrm{~m}^{2}$. Наведена типова система зі штучними озерами мала в десять разів більшу потужність та займала в десять разів більшу площу [8]. Тобто, вибір між системами суттєво залежить від встановленого рівня теплоспоживання об'єкту.

Наведена далі вартість розглянутих систем стосується лише певної частки спожитої теплоти. Ця частка може значно коливатись в залежності від того, що є резервним джерелом теплоти в розглянутій системі. Наприклад, в [44] вважалось, що система центрального теплопостачання 3 системою сезонного геотермального акумулювання в комбінації 3 котлами на природному газі може бути на 100 \% забезпечена за рахунок сезонного геотермального акумулювання, в той час як в [8] вважалось, що ступінь забезпечення має складати в середньому $50 \%$, що відповідає впровадженим проектам [45].

При визначенні економічної доцільності впровадження центрального теплопостачання 3 системою сезонного геотермального акумулювання необхідно спиратись на нормовану вартість теплоти [8], що враховує собівартість виробництва теплоти протягом усього циклу роботи такої системи (включно 3 усіма можливими інвестиціями, витратами та прибутками). Наведені в [8] значення номінальної вартості теплопостачання для розглянутих систем порівняємо 3 дійсною вартістю центрального теплопостачання в Україні (на прикладі м. Києва) та інших країн Європи (табл. 3). Відносна різниця нормованої вартості теплоти від центрального теплопостачання 3 сезонним геотермальним акумулюванням у порівнянні $з$ дійсною вартістю центрального теплопостачання в країні $b_{\text {варт, }} \%$ :

$$
b_{\text {варт }}=\frac{B_{\text {гео }}-B_{\text {чтT }}}{B_{\text {цт }}} \cdot 100 \%,
$$

де $B_{\text {гео }}$ - нормована вартість теплоти від центрального теплопостачання 3 сезонним геотермальним акумулюванням: 3 використанням свердловин становила 2970...4880 грн/Гкал для умов Центральної Європи в 2016 році, а для систем 3 використанням штучних озер $1310 \ldots 1760$ грн/Гкал [8]; $B_{u m}$ - дійсна вартість центрального теплопостачання в країні, грн/Гкал.

Наведені дані показують, що вартість центрального теплопостачання в Україні залишається однією з найнижчих в Свропі. При цьому в Україні така вартість опалення формується цінами традиційних джерел енергії (переважно природного газу). Варто відзначити, що низька вартість центрального теплопостачання в Данії може бути частково обгрунтована тим, що дана країна $\epsilon$ лідером з впровадження технологій центрального теплопостачання від систем сезонного геотермального акумулювання [46]. 
Нормована вартість центрального теплопостачання за використання сезонного геотермального акумулювання в Данії є помітно нижчою за осереднені дані, представлені в [8]: $560 \ldots 1110$ грн/Гкал. Таке значення вартості було досягнене й за рахунок державної допомоги зі створення цих систем - без неї вартість центрального теплопостачання від системи сезонного геотермального акумулювання була б вищою [45]. В літературі наводять й вищі значення вартості центрального теплопостачання від систем сезонного геотермального акумулювання в Данії: так, в [47] вона сягала 1370 грн/Гкал, що все одно є меншим за вартість центрального теплопостачання в Україні.

Таблиця 3. Порівняння вартості традиційного центрального теплопостачання та центрального теплопостачання від системи з використанням сезонного геотермального акумулювання.

Table 3. The comparison of the levelized cost of energy of convenient district heating systems and solar district heating with seasonal thermal energy storage.

\begin{tabular}{|c|c|c|c|c|c|c|}
\hline Характеристика & Україна & Естонія & Латвія & Данія & Чехія & Словаччина \\
\hline $\begin{array}{l}\text { Вартість центрального } \\
\text { теплопостачання } B_{\text {трад, грн/Гкал }}\end{array}$ & 1650 & 2640 & 2210 & 2330 & 2850 & 3280 \\
\hline $\begin{array}{l}\text { Відносна різниця вартості } \\
\text { центрального теплопостачання від } \\
\text { системи сезонного геотермального } \\
\text { акумулювання у порівнянні } 3 \\
\text { середньою вартістю центрального } \\
\text { теплопостачання в країні } b_{\text {варт }} \%, \\
\text { за застосування: }\end{array}$ & & & & & & \\
\hline & $80 \ldots 200$ & $10 \ldots 80$ & $30 \ldots 120$ & $30 \ldots 110$ & $4 \ldots 70$ & $-10 \ldots 50$ \\
\hline штучних озер & $-20 \ldots 7$ & $-50 \ldots-30$ & $-40 \ldots-20$ & $-40 \ldots-20$ & $-50 \ldots-40$ & $-60 \ldots-50$ \\
\hline
\end{tabular}

Примітка: вартість центрального теплопостачання в інших країнах узято з [48], для України - [49].

Загалом, дані 3 табл. 3 демонструють, що вартість центрального теплопостачання від систем 3 використанням свердловин на даному етапі в переважній більшості країн залишається порівняно дорожчим рішенням, ніж застосування традиційних систем. Водночас, вартість центрального теплопостачання від систем 3 використанням штучних озер $є$ значно дешевшою за дійсну вартість центральне теплопостачання, навіть в умовах України.

Що стосується вартості технології сезонного геотермального акумулювання теплової енергії, то вона, навпаки, надалі має знижуватись.

Таким чином, впровадження систем центрального теплопостачання $з$ використанням сезонного геотермального акумулювання за допомогою штучних озер $є$ обмеженим лише наявністю відповідних площ під впровадження таких систем та значним рівнем початкових інвестицій в такі проекти [50]. На відміну від традиційних систем теплопостачання, більша частина вартості яких становить вартість палива (природного газу), в запропонованих системах найбільшу частку вартості формує власне конструкція системи [45,49]. Але за умови державної підтримки можливим є впровадження хоч і більш витратної, але в рази більш компактної системи сезонного геотермального акумулювання 3 використанням свердловин.

\section{Висновки.}

1. Збільшення частки відновлюваної енергетики в загальному енергопостачанні призводить до потреби комплексного аналізу комбінованої роботи різних систем виробництва енергії. В першу чергу це стосується тих джерел, виробництво енергії якими $є$ непостійним у часі, особливо якщо розглядати його в рамках сезонної генерації тепла, наприклад, надлишкової генерації теплоти та електроенергії від джерел сонячної 
енергії в теплий період та значне зменшення такої генерації в холодний період року.

2. Досить перспективним засобом економії

$\epsilon$ перетворення надлишково виробленої електроенергії в водень для використання в таких напрямках як теплопостачання будівель та паливо для транспорту. Що стосується застосування водню як джерела палива для пасажирського транспорту, то автомобільні концерни поки що мають суперечливі погляди щодо перспектив цієї технології.

3. Проведений аналіз сезонних систем акумулювання показав, що дані в літературі щодо тих чи інших типів систем сезонного геотермального акумулювання $€$ досить суперечливими. Серед наведених типів систем сезонного геотермального акумулювання найбільш прийнятними вважаються системи 3 використанням свердловин та системи 3 використанням штучних озер. Системи відрізняються рекомендованим діапазоном теплової потужності, яку вони повинні забезпечувати. Типове значення потужності системи 3 використанням свердловин становить 3,5 МВт, а для систем 3 використанням штучних озер воно є вдесятеро більшим.

4. Була проаналізована

можливість поєднання системи сезонного геотермального акумулювання 3 використанням свердловин та системи водневого теплопостачання. Даний аналіз створює засади подальших досліджень задля вдосконалення окремих елементів даної системи: системи водневого теплопостачання, системи генерації та акумулювання теплоти, системи генерації електроенергії та іï розподілення тощо.

5. Економічний аналіз показав, що у випадку України нормована вартість системи центрального теплопостачання до складу якої входить сезонний геотермальний акумулятор, в якому застосовано технологію свердловин, $\epsilon$ вищою на $80 . .200 \%$. за вартість центрального теплопостачання від традиційних джерел енергії. Водночас, системи з застосуванням штучних озер можуть бути дешевшими на $20 \%$, але їх встановлення потребуватиме значних початкових інвестицій.
1. Gielen D. et al. The role of renewable energy in the global energy transformation. Energy Strategy Reviews. 2019. Vol. 24. Pp. 38-50. https://doi.org/10.1016/j.esr.2019.01.006.

2. Widera $B$. Renewable hydrogen implementations for combined energy storage, transportation and stationary applications. Thermal Science and Engineering Progress. 2020. Vol. $16 . \quad$ Pp. 100460. https://doi.org/10.1016/j.tsep.2019.100460.

3. Hirth $L$. The market value of variable renewables. Energy Econ. 2013. Vol. 38. pp. 218-236. https://doi.org/10.1016/j.eneco.2013.02.004

4. Bravo R., Friedrich D. Integration of energy storage with hybrid solar power plants. Energy Procedia. 2018. Vol. 151. Pp. 182-186.

5. Бекман Г., Гилли П. Тепловое аккумулирование энергии. М. Мир. 1987. 272 с.

6. Matos C.R., Carneiro J.F., Silva P.P. Overview of Large-Scale Underground Energy Storage Technologies for Integration of Renewable Energies and Criteria for Reservoir Identification. Journal of Energy Storage. 2019. Vol. 21. Pp. 241-258. https://doi.org/10.1016/j.est.2018.11.023.

7. Karki S., Haapala K.R., Fronk B.M. Technical and economic feasibility of solar flat-plate collector thermal energy systems for small and medium manufacturers. Applied Energy. 2019. Vol. 254. Pp. 113649. https://doi.org/10.1016/j.apenergy.2019.113649.

8. Mauthner F. IEA SHC Task 52: Solar Thermal and Energy Economy in Urban Environments: TECHNOLOGY AND DEMONSTRATORS Technical Report Subtask C - Part C1: Classification and benchmarking of solar thermal systems in urban environments. [Електронний pecypc]. URL: https://task52.iea-shc.org/Data/Sites/1/publications/IEASHC-Task52-STC1-Classification-andBenchmarking_v02.pdf (дата звернення: 09.06.2020).

9. Van der Roest E. et al. Introducing Power-to-H3: Combining renewable electricity with heat, water and hydrogen production and storage in a neighbourhood. Applied Energy. 2020. Vol. 257. Pp. 114024. https://doi.org/10.1016/j.apenergy.2019.114024.

10. Mesquita L. et al. Drake Landing Solar Community: 10 Years of Operation. Proceedings of SWC2017/SHC2017. Freiburg. Germany. International Solar Energy Society. 2017. Pp. 1-12. https://doi.org/10.18086/swc.2017.06.09.

11. Dawood F., Anda M., Shafiullah G.M. Hydrogen production for energy: An overview. International Journal of Hydrogen Energy. 2020. Vol. 45. № 7. Pp. 3847-3869. https://doi.org/10.1016/j.ijhydene.2019.12.059.

12. Crowl D.A., Jo Y.-D. The hazards and risks of hydrogen. J. Loss Prev. Process Ind. 2007. Vol. 20. № 2. Pp. 158-164. https://doi.org/10.1016/j.jlp.2007.02.002.

13. Dodds P.E. et al. Hydrogen and fuel cell technologies for heating. A review. International Journal of 
Hydrogen Energy. 2015. Vol. 40. № 5. Pp. 2065-2083. https://doi.org/10.1016/j.ijhydene.2014.11.059.

14. Nastasi B., Lo Basso G. Hydrogen to link heat and electricity in the transition towards future Smart Energy Systems. Energy. 2016. Vol. 110. Pp. 5-22. https://doi.org/10.1016/j.energy.2016.03.097.

15. Hydrogen Council: Path to hydrogen competitiveness A cost perspective: 20 January 2020. [Електронний ресурс]. URL: https://hydrogencouncil.co m/wp-content/uploads/2020/01/Path-to-Hydrogen-

Competitiveness_Full-Study-1.pdf. (дата звернення: 09.06.2020).

16. Ellamla H.R. et al. Current status of fuel cell based combined heat and power systems for residential sector. J. Power Sources. 2015. Vol. 293. Pp. 312-328. https://doi.org/10.1016/j.jpowsour.2015.05.050.

17. Development of FPS (fuel processing system) for ENE-FARM. [Електронний pecypc]. URL: https://www.tokyogas.co.jp/techno/english/category $1 / 5$ index_detail.html. (дата звернення: 10.06.2020).

18. Wilberforce T. et al. Developments of electric cars and fuel cell hydrogen electric cars. International Journal of Hydrogen Energy. 2017. Vol. 42. № 40. Pp. 25695-25734.

https://doi.org/10.1016/j.ijhydene.2017.07.054.

19. Battery or fuel cell, that is the question. [Електронний ресурс]. URL: https://www.volkswagennewsroom.com/en/stories/battery-or-fuel-cell-that-is-thequestion-5868. (дата звернення: 12.06.2020).

20. Hyundai Hydrogen Chief on Why the Company Bet on Fuel Cells. [Електронний pecypc]. URL: https://www.bloomberg.com/news/articles/2020-0609/hyundai-s-hydrogen-chief-on-why-the-auto-giant-beton-fuel-cells. (дата звернення: 12.06.2020).

21. Sharma A. et al. Review on thermal energy storage with phase change materials and applications. Renew. Sustain. Energy Rev. 2009. Vol. 13. № 2. Pp. 318345. https://doi.org/10.1016/j.rser.2007.10.005.

22. Mehling H., Cabeza L.F. Heat and cold storage with PCM. Berlin. Heidelberg: Springer Berlin Heidelberg. 2008. https://doi.org/10.1007/978-3-540-68557-9.

23. Zalba B. et al. Review on thermal energy storage with phase change: materials, heat transfer analysis and applications. Applied Thermal Engineering. 2003. Vol. 23. № 3. Pp. 251-283. https://doi.org/10.1016/S13594311(02)00192-8.

24. Lizana J. et al. Advances in thermal energy storage materials and their applications towards zero energy buildings: A critical review. Applied Energy. 2017. Vol. 203. Pp. 219239.https://doi.org/10.1016/j.apenergy.2017.06.008.

25. Shah S.K., Aye L., Rismanchi B. Seasonal thermal energy storage system for cold climate zones: A review of recent developments. Renewable and Sustainable Energy Reviews. 2018. Vol. 97. Pp. 38-49. https://doi.org/10.1016/j.rser.2018.08.025.
26. Xu J., Wang R.Z., Li Y. A review of available technologies for seasonal thermal energy storage. Solar Energy. 2014. Vol. 103. Pp. 610-638. https://doi.org/10.1016/j.solener.2013.06.006.

27. Hesaraki A., Holmberg S., Haghighat F. Seasonal thermal energy storage with heat pumps and low temperatures in building projects. A comparative review. Renewable and Sustainable Energy Reviews. 2015. Vol. 43. Pp. 1199-1213.

https://doi.org/10.1016/j.rser.2014.12.002.

28. Bedouani B.Y. et al. Central electric thermal storage (ETS) feasibility for residential applications: Part 2. Techno-economic study. International Journal of Energy Research. 2001. Vol. 25. № 1. Pp. 73-83. https://doi.org/10.1002/1099-

\section{X(200101)25:1<73::AID-ER611>3.0.CO;2-K.}

29. Cruickshank A.C., Baldwin C. Sensible Thermal Energy Storage: Diurnal and Seasonal. Storing Energy. Elsevier. 2016. Pp. 291-311. https://doi.org/10.1016/B9780-12-803440-8.00015-4.

30. Mangold D., Deschaintre L. Seasonal thermal energy storage: Report on state of the art and necessary further R+D. [Електронний pecypc]. URL: http://task45.iea-

shc.org/data/sites/1/publications/IEA_SHC_Task45_B_Re port.pdf (дата звернення 12.05.2020).

31. Guideline for Seasonal Thermal Energy Storage in the Built Environment. [Електронний ресурc]. URL: http://www.ectp.org/fileadmin/user_upload/documents/E2 B/EINSTEIN/einstein-guidelines_stes-tanks-del-38.pdf. (дата звернення 12.05.2020).

32. Rad F.M., Fung A.S. Solar community heating and cooling system with borehole thermal energy storage Review of systems. Renewable and Sustainable Energy Reviews. 2016. Vol. 60. Pp. 1550-1561. https://doi.org/10.1016/j.rser.2016.03.025.

33. Schmidt T., Mangold D., Müller-Steinhagen $H$. Seasonal thermal energy storage in Germany. ISES Solar World Congress. 14-19 June. Göteborg. Schweden. 2003.

34. Fleuchaus $P$. et al. Worldwide application of aquifer thermal energy storage. A review. Renewable and Sustainable Energy Reviews. 2018. Vol. 94. Pp. 861-876. https://doi.org/10.1016/j.rser.2018.06.057.

35. Lanahan M., Tabares-Velasco P.C. Seasonal Thermal-Energy Storage: A Critical Review on BTES Systems, Modeling, and System Design for Higher System Efficiency. Energies. 2017. Vol. 10. № 6. 743 p. https://doi.org/10.3390/en10060743.

36. Ebrahimi M., Keshavarz A. CCHP Thermal Energy Storage. Combined Cooling, Heating and Power. Elsevier. 2015. Pp. 183-188. https://doi.org/10.1016/B9780-08-099985-2.00008-1.

37. Sommer W.T. et al. Thermal performance and heat transport in aquifer thermal energy storage. Hydrogeology Journal. 2014. Vol. 22. № 1. Pp. 263-279. https://doi.org/10.1007/s10040-013-1066-0. 
38. Gao L. et al. A review on system performance studies of aquifer thermal energy storage. Energy Procedia. 2017. Vol. 142. Pp. $3537-$ 3545. https://doi.org/10.1016/j.egypro.2017.12.242.

39. Sibbit B. et al. Groundbreaking Solar Case Study : Drake Landing Solar Community. High Performing Buildings. 2015.

40. Sibbitt B. et al. The Performance of a High Solar Fraction Seasonal Storage District Heating System - Five Years of Operation. Energy Procedia. 2012. Vol. 30. Pp. 856-865. https://doi.org/10.1016/j.egypro.2012.11.097.

41. Pardo García N. et al. Photovoltaic thermal hybrid solar collector and district heating configurations for a Central European multi-family house. Energy Conversion and Management. 2017. Vol. 148. Pp. 915-924. https://doi.org/10.1016/j.enconman.2017.05.065.

42. Khelifa A. et al. Analysis of a Hybrid Solar Collector Photovoltaic Thermal (PVT). Energy Procedia. 2015. Vol. 74. Pp. 835-843. https://doi.org/10.1016/j.egypro.2015.07.819.

43. Q \& A: DLR's Christian Sattler on the Role of Solar Thermochemistry in Green Hydrogen Production. [Електронний pecypc]. URL: https://www.solarpaces.org/csp-efficient-solar-splith2o-hydrogen/. (дата звернення: 07.06.2020).

44. Huang J. et al. Economic analysis and optimization of combined solar district heating technologies and systems. Energy. 2019. Vol. 186. 115886 p. https://doi.org/10.1016/j.energy.2019.115886.

45. Denmark: 23 MWth Cover $55 \%$ of Heat Demand of 1,500 Households. [Електронний pecypc]. URL: https://www.solarthermalworld.org/news/denmark23-mwth-cover-55-heat-demand-1500-households. (дата звернення 15.06.2020).

46. Tian Z. et al. Large-scale solar district heating plants in Danish smart thermal grid: Developments and recent trends. Energy Conversion and Management. 2019. Vol. 189. Pp. 67-80. https://doi.org/10.1016/j.enconman.2019.03.071.

47. Tschopp D. et al. Large-scale solar thermal systems in leading countries: A review and comparative study of Denmark, China, Germany and Austria. Applied Energy. 2020. Vol. 270. 114997 p. https://doi.org/10.1016/j.apenergy.2020.114997.

48. Загальноукраїнська інформація та статистична інформація європейських інституцій у сфері централізованого опалення та централізованого постачання гарячої води. [Електронний ресурс]. URL: http://www.nerc.gov.ua/?id=39305. (дата звернення 12.06.2020).

49. Київтеплоенерго : 3 січня 2019 року в КП «Київтеплоенерго» діють нові тарифи на централізоване постачання гарячої води та централізоване опалення. [Електронний ресурс]. URL: https://kte.kmda.gov.ua/z-sichnya-2019-roku-v-kpkyyivteploenergo-diyut-novi-taryfy-na-tsentralizovane- postachannya-garyachoyi-vody-ta-tsentralizovaneopalennya/. (дата звернення: 09.06.2020).

50. Narula K. et al. Assessment of techno-economic feasibility of centralised seasonal thermal energy storage for decarbonising the Swiss residential heating sector. Renewable Energy. 2020. Vol. 161. Pp. 1209-1225. https://doi.org/10.1016/j.renene.2020.06.099.

\section{REFERENCES}

1. Gielen D. et al. The role of renewable energy in the global energy transformation. Energy Strategy Reviews. 2019. Vol. 24. Pp. 38-50. https://doi.org/10.1016/j.esr.2019.01.006. [in English].

2. Widera $B$. Renewable hydrogen implementations for combined energy storage, transportation and stationary applications. Thermal Science and Engineering Progress. 2020. Vol. $16 . \quad$ Pp. 100460. https://doi.org/10.1016/j.tsep.2019.100460. [in English].

3. Hirth $L$. The market value of variable renewables. Energy Econ. 2013. Vol. 38. Pp. 218-236. https://doi.org/10.1016/j.eneco.2013.02.004. [in English].

4. Bravo R., Friedrich D. Integration of energy storage with hybrid solar power plants. Energy Procedia. 2018. Vol. 151. Pp. 182-186. [in English].

5. Beckmann G., Gilli P.V. Teplovoe akkumulirovanie energii. [Thermal energy storage]. Mir. 1987. 272 p. [in Russian].

6. Matos C.R., Carneiro J.F., Silva P.P. Overview of Large-Scale Underground Energy Storage Technologies for Integration of Renewable Energies and Criteria for Reservoir Identification. Journal of Energy Storage. 2019. Vol. 21. Pp. 241-258. https://doi.org/10.1016/j.est.2018.11.023. [in English].

7. Karki S., Haapala K.R., Fronk B.M. Technical and economic feasibility of solar flat-plate collector thermal energy systems for small and medium manufacturers. Applied Energy. 2019. Vol. 254. Pp. 113649. https://doi.org/10.1016/j.apenergy.2019.113649. [in English].

8. Mauthner F. IEA SHC Task 52: Solar Thermal and Energy Economy in Urban Environments: TECHNOLOGY AND DEMONSTRATORS Technical Report Subtask C - Part C1: Classification and benchmarking of solar thermal systems in urban environments. [Electronic resource]. URL: https://task52.iea-shc.org/Data/Sites/1/publications/IEASHC-Task52-STC1-Classification-and-

Benchmarking_v02.pdf (Applying date: 09.06.2020). [in English].

9. Van der Roest E. et al. Introducing Power-to-H3: Combining renewable electricity with heat, water and hydrogen production and storage in a neighbourhood. Applied Energy. 2020. Vol. 257. Pp. 114024. https://doi.org/10.1016/j.apenergy.2019.114024. [in English]. 
10. Mesquita L. et al. Drake Landing Solar Community: 10 Years of Operation. Proceedings of SWC2017/SHC2017. Freiburg. Germany. International Solar Energy Society. 2017. Pp. 1-12. https://doi.org/10.18086/swc.2017.06.09. [in English].

11. Dawood F., Anda M., Shafiullah G.M. Hydrogen production for energy: An overview. International Journal of Hydrogen Energy. 2020. Vol. 45. No. 7. Pp. 3847-3869. https://doi.org/10.1016/j.ijhydene.2019.12.059. [in English].

12. Crowl D.A., Jo Y.-D. The hazards and risks of hydrogen. J. Loss Prev. Process Ind. 2007. Vol. 20. No. 2. Pp. 158-164. https://doi.org/10.1016/j.jlp.2007.02.002. [in English].

13. Dodds P.E. et al. Hydrogen and fuel cell technologies for heating. A review. International Journal of Hydrogen Energy. 2015. Vol. 40. No. 5. Pp. 2065-2083. https://doi.org/10.1016/j.ijhydene.2014.11.059.

[in English].

14. Nastasi B., Lo Basso G. Hydrogen to link heat and electricity in the transition towards future Smart Energy Systems. Energy. 2016. Vol. 110. Pp. 5-22. https://doi.org/10.1016/j.energy.2016.03.097. [in English].

15. Hydrogen Council: Path to hydrogen competitiveness A cost perspective: 20 January 2020. [Electronic resource]. URL: https://hydrogencouncil.com/wpcontent/uploads/2020/01/Path-to-Hydrogen-

Competitiveness_Full-Study-1.pdf. (Applying date: 09.06.2020). [in English].

16. Ellamla H.R. et al. Current status of fuel cell based combined heat and power systems for residential sector. J. Power Sources. 2015. Vol. 293. Pp. 312-328. https://doi.org/10.1016/j.jpowsour.2015.05.050. [in English].

17. Development of FPS (fuel processing system) for ENE-FARM. [Electronic resource]. URL: https://www.tokyogas.co.jp/techno/english/category1/5 index detail.html. (Applying date: 10.06.2020). [in English].

18. Wilberforce T. et al. Developments of electric cars and fuel cell hydrogen electric cars. International Journal of Hydrogen Energy. 2017. Vol. 42. No. 40. Pp. 25695-25734.

https://doi.org/10.1016/j.ijhydene.2017.07.054.

[in English].

19. Battery or fuel cell, that is the question. [Electronic resource]. URL: https://www.volkswagennewsroom.com/en/stories/battery-or-fuel-cell-that-is-thequestion-5868. (Applying date: 12.06.2020). [in English].

20. Hyundai Hydrogen Chief on Why the Company Bet on Fuel Cells. [Electronic resource]. URL: https://www.bloomberg.com/news/articles/2020-06-

09/hyundai-s-hydrogen-chief-on-why-the-auto-giant-beton-fuel-cells. (Applying date: 12.06.2020). [in English].

21. Sharma A. et al. Review on thermal energy storage with phase change materials and applications. Renew. Sustain. Energy Rev. 2009.
Vol. 13. No. 2. Pp. 318-345.

https://doi.org/10.1016/j.rser.2007.10.005. [in English].

22. Mehling H., Cabeza L.F. Heat and cold storage with PCM. Berlin. Heidelberg: Springer Berlin Heidelberg. 2008. https://doi.org/10.1007/978-3-540-68557-9. [in English].

23. Zalba B. et al. Review on thermal energy storage with phase change: materials, heat transfer analysis and applications. Applied Thermal Engineering. 2003. Vol. 23. No. 3. Pp. 251-283. https://doi.org/10.1016/S13594311(02)00192-8. [in English].

24. Lizana J. et al. Advances in thermal energy storage materials and their applications towards zero energy buildings: A critical review. Applied Energy. 2017. Vol. 203. Pp. 219-239.

https://doi.org/10.1016/j.apenergy.2017.06.008. [in English].

25. Shah S.K., Aye L., Rismanchi B. Seasonal thermal energy storage system for cold climate zones: A review of recent developments. Renewable and Sustainable Energy Reviews. 2018. Vol. 97. Pp. 38-49. https://doi.org/10.1016/j.rser.2018.08.025. [in English].

26. Xu J., Wang R.Z., Li Y. A review of available technologies for seasonal thermal energy storage. Solar Energy. 2014. Vol. 103. Pp. 610-638. https://doi.org/10.1016/j.solener.2013.06.006. [in English].

27. Hesaraki A., Holmberg S., Haghighat F. Seasonal thermal energy storage with heat pumps and low temperatures in building projects. A comparative review. Renewable and Sustainable Energy Reviews. 2015. Vol. 43. Pp. 1199-1213.

https://doi.org/10.1016/j.rser.2014.12.002. [in English].

28. Bedouani B.Y. et al. Central electric thermal storage (ETS) feasibility for residential applications: Part 2. Techno-economic study. International Journal of Energy Research. 2001. Vol. 25. No. 1. Pp. 73-83. https://doi.org/10.1002/1099$114 \mathrm{X}(200101) 25: 1<73:$ :AID-ER611>3.0.CO;2-K. [in English].

29. Cruickshank A.C., Baldwin C. Sensible Thermal Energy Storage: Diurnal and Seasonal. Storing Energy. Elsevier. 2016. Pp. 291-311. https://doi.org/10.1016/B9780-12-803440-8.00015-4. [in English].

30. Mangold D., Deschaintre L. Seasonal thermal energy storage: Report on state of the art and necessary further R+D. [Electronic resource]. URL: http://task45.ieashc.org/data/sites/1/publications/IEA_SHC_Task45_B_Re port.pdf (Applying date: 12.05.2020). [in English].

31. Guideline for Seasonal Thermal Energy Storage in the Built Environment. [Electronic resource]. URL: http://www.ectp.org/fileadmin/user_upload/docume nts/E2B/EINSTEIN/einstein-guidelines_stes-tanks-del38.pdf. (Applying date: 12.05.2020). [in English].

32. Rad F.M., Fung A.S. Solar community heating and cooling system with borehole thermal energy storage Review of systems. Renewable and Sustainable Energy 
Reviews. 2016. Vol. 60. Pp. 1550-1561.

https://doi.org/10.1016/j.rser.2016.03.025. [in English].

33. Schmidt T., Mangold D., Müller-Steinhagen H. Seasonal thermal energy storage in Germany. ISES Solar World Congress. 14-19 June. Göteborg. Schweden. 2003. [in English].

34. Fleuchaus $P$. et al. Worldwide application of aquifer thermal energy storage. A review. Renewable and Sustainable Energy Reviews. 2018. Vol. 94. Pp. 861-876. https://doi.org/10.1016/j.rser.2018.06.057. [in English].

35. Lanahan M., Tabares-Velasco P.C. Seasonal Thermal-Energy Storage: A Critical Review on BTES Systems, Modeling, and System Design for Higher System Efficiency. Energies. 2017. Vol. 10. No. 6. 743 p. https://doi.org/10.3390/en10060743. [in English].

36. Ebrahimi M., Keshavarz A. CCHP Thermal Energy Storage. Combined Cooling, Heating and Power. Elsevier. 2015. Pp. 183-188. https://doi.org/10.1016/B9780-08-099985-2.00008-1. [in English].

37. Sommer W.T. et al. Thermal performance and heat transport in aquifer thermal energy storage. Hydrogeology Journal. 2014. Vol. 22. No. 1. Pp. 263-279. https://doi.org/10.1007/s10040-013-1066-0. [in English].

38. Gao L. et al. A review on system performance studies of aquifer thermal energy storage. Energy Procedia. 2017. Vol. 142. Pp. 3537-3545. https://doi.org/10.1016/j.egypro.2017.12.242. [in English].

39. Sibbit B. et al. Groundbreaking Solar Case Study: Drake Landing Solar Community. High Performing Buildings. 2015. [in English].

40. Sibbitt B. et al. The Performance of a High Solar Fraction Seasonal Storage District Heating System - Five Years of Operation. Energy Procedia. 2012. Vol. 30. Pp. 856-865. https://doi.org/10.1016/j.egypro.2012.11.097. [in English].

41. Pardo García N. et al. Photovoltaic thermal hybrid solar collector and district heating configurations for a Central European multi-family house. Energy Conversion and Management. 2017. Vol. 148. Pp. 915-924. https://doi.org/10.1016/j.enconman.2017.05.065.

[in English].

42. Khelifa A. et al. Analysis of a Hybrid Solar Collector Photovoltaic Thermal (PVT). Energy Procedia. 2015. Vol. 74. Pp. 835-843. https://doi.org/10.1016/j.egypro.2015.07.819. [in English].

43. Q \& A: DLR's Christian Sattler on the Role of Solar Thermochemistry in Green Hydrogen Production. [Electronic resource]. URL: https://www.solarpaces.org/csp-efficientsolar-split-h2o-hydrogen/. (Applying date: 07.06.2020). [in English].
44. Huang J. et al. Economic analysis and optimization of combined solar district heating technologies and systems. Energy. 2019. Vol. 186. 115886 p. $\quad$ https://doi.org/10.1016/j.energy.2019.115886. [in English].

45. Denmark: 23 MWth Cover 55\% of Heat Demand of 1,500 Households. [Electronic resource]. URL: https://www.solarthermalworld.org/news/denmark-23-

mwth-cover-55-heat-demand-1500-households. (Applying date: 15.06.2020). [in English].

46. Tian Z. et al. Large-scale solar district heating plants in Danish smart thermal grid: Developments and recent trends. Energy Conversion and Management. 2019. Vol. 189. Pp. 67-80. https://doi.org/10.1016/j.enconman.2019.03.071.

[in English].

47. Tschopp D. et al. Large-scale solar thermal systems in leading countries: A review and comparative study of Denmark, China, Germany and Austria. Applied Energy 2020. Vol. 270. 114997 p. https://doi.org/10.1016/j.apenergy.2020.114997.

[in English].

48. Zahalnoukrainska informatsiia ta statystychna informatsiia yevropeiskykh instytutsii u sferi tsentralizovanoho opalennia ta tsentralizovanoho postachannia hariachoi vody. [All-Ukrainian information and statistical information of European institutions in the field of district heating and centralized hot water supply]. [Electronic resource]. URL:http://www.nerc.gov.ua/?id=3 9305. (Applying date: 12.06.2020). [in Ukrainian].

49. Kyivteploenerho: Z sichnia 2019 roku v KP «Kyivteploenerho» diiut novi taryfy na tsentralizovane postachannia hariachoi vody ta tsentralizovane opalennia. [Kyivteploenerho: Since January 2019, municipally owned corporation Kyivteploenerho has introduced new tariffs for district hot water supply and district heating]. [Electronic resource]. URL: https://kte.kmda.gov.ua/z-sichnya-2019roku-v-kp-kyyivteploenergo-diyut-novi-taryfy-natsentralizovane-postachannya-garyachoyi-vody-tatsentralizovane-opalennya/. (Applying date: 09.06.2020). [in Ukrainian].

50. Narula K. et al. Assessment of techno-economic feasibility of centralised seasonal thermal energy storage for decarbonising the Swiss residential heating sector. Renewable Energy. 2020. Vol. 161. Pp. 1209-1225. https://doi.org/10.1016/j.renene.2020.06.099. [in English].

Стаття надійшла до редакції 20.07.20 Остаточна версія 18.09.20 